\title{
Overreaction Hypothesis and Reaction of Borsa Istanbul to Dow-Jones
}

\author{
Metin Tetik \\ Usak University, Turkey \\ E-mail: metin.tetik@usak.edu.tr \\ Ercan Özen \\ Usak University, Turkey
}

Received: November 4, 2016

Accepted: November 30, 2016

doi:10.5296/ber.v6i2.10353

URL: http://dx.doi.org/10.5296/ber.v6i2.10353

\begin{abstract}
The aim of this study is to investigate whether or not there are any over-reactions to the positive and negative events of the Borsa Istanbul 100 index (BIST-100) in relation to the Dow Jones Industrial index (DJIA). The daily stock indexes between January 2010 and June 2016 are used in this research. The research finding showed that BIST-100 reacts in the same way as DJIA up to $3.31 \%$ and the reaction decreases and was lost between 30 and 60 days against the positive changes. In case of adverse events the BIST 100 shows abnormal decline in protecting the efficient market hypothesis is valid for 30 days after the event, however, the decline is reversed until the 60'th days when all losses are compensated. This terminates the validity of the efficient market hypothesis. This study shows that the BIST 100 index does not comply with the efficient market hypothesis and demonstrate the validity of the overreaction hypothesis. Study results include stock investments, whose findings will have an impact on portfolio management decisions of investors.
\end{abstract}

Keywords: Overreaction Hypothesis, Efficient Markets Hypothesis, BIST, DOW

\section{Introduction}

As the globalization trends in the world are everywhere, financial markets have also been intensely affected. The increase of social, cultural and economic relations among the countries has made the whole Earth into a single village. Trade, co-production and technology-sharing movements in a region have also affected other regions of the world. Stock exchanges have become significantly integrated as an inevitable consequence of this 
interaction. A move on a stock exchange leads to a certain amount of movement on the stock exchange of another country.

In the global stock exchanges, the New York stock exchange is one of the most important stock exchanges of the World. The Dow Jones Industrial Avarage Index (DJIA), which is the most important indicator of the New York Stock Exchange, is used as a bencmark for many markets, and many investors have decided to trade in their own country based on the price movements there. Borsa Istanbul (BIST), a developing stock exchange, closely follows the developments experienced in the Dow Jones index like other stock exchanges. Against an upward movement in DJIA, the BIS indexes are mostly responding to an increase. The decline in DJIA has also led to a decline in ICT in a similar way.

At the beginning of 2016, the total market value of BIST-100 companies is 215 billion USD while the market value of DJIA 30 companies is around 5,262.8 billion USD. The GDP of Turkey is 733.6 billion dollars in 2015, while the GDP of the United States is 17.947 billion dollars. When the size of the US economy and Dow Jones is compared with the size of the Turkish economy and the Borsa Istanbul, it is natural that the Borsa Istanbul is affected by the US market. At the BIST process, while Turkey is at 16:30, DJIA starts spot operations and ends at 23:00 with Turkey time. The next day BIST is shaped by the closing price at the opening Dow Jones.

Traders trading in the BIST track DJIA and are overly optimistic in favor of positive developments and trading in extreme pessimism in the face of adverse developments. Following this excessive price, prices can return to their former position again. In this case, some investors may be buying from excessively rising prices, or they may be in a loss as a result of selling at extremely low prices. An investor who learns that the market is behaving like this can go on the market to buy and sell, thinking that prices can reverse. Thus, the investor can earn more than expected. The occurrence of such extremes on the stock markets reveals the existence of the Hypothesis of Overreaction. This leads to the question of the validity of the Efficient Market hypothesis.

The aim of the study is to investigate whether the reactions of the BIST-100 to the DJIA are excessive. The second part of the study examines the hypothesis of the overreaction against the efficient market hypothesis, which is designed in the form of a literature review, methods and findings, and general evaluation.

\section{Overreaction Hypothesis}

The overreaction hypothesis is based on some findings that are inconsistent with the effecient market hypothesis posed by Fama (1970). There are two main points that distinguish between the two hypotheses. At first, the effecient market hypothesis suggests that investors will not change prices until after a post-transaction. The hypothesis of overreaction, on the other hand, says that after an information comes the prices will move forward in a certain direction but will return to the old level again in the next few days without any new knowledge.

Market efficiency implied by Fama is an information based activity. Fama (1970: 383) defines the effecient market as "full reflection of all available information on prices". There 
are three forms of effecient market. The province is weak market efficiency. The weak form of efficiency assumes that investors will not be able to earn excess earnings using past price information. The second type of market efficiency in semi-strong form means that investors will not be able to provide returns above market returns using publicly disclosed information as well as past price information. The third form, the strong form of market efficiency, assumes that learners who are not informed of the public can not earn high profits.

The overreaction is defined as the excessive increase / decrease in stock prices for continuous and consistent information showing the same direction in the long run (Barak, 2008a: 159). The overreaction hypothesis states that stock prices are very sensitive to a new wisdom. In positive events, stock prices outperformed average yields. On the other hand, after a certain period of time prices have collapsed and prices have come back to more realistic levels since investors have gone to very high share prices (De Medeiros, 2005: 2).

According to DeBondt and Thaler (1985: 795), if stock prices are systematically excessively reversed, prices can be determined by looking at historical yields only, without using any accounting data such as profit. Two hypotheses are proposed for this interest:

I. Stock movements are followed by extreme movements in the opposite direction.

II. The more the initial price movements, the greater the subsequent adjustments.

In this case, an investor can use this information to gain a return above the market turnover thanks to the trading strategies it implements. In such a case, these two hypotheses are in violation of weak market activity. Because weak market activity suggests that excessive returns cannot be achieved using past market data.

At the beginning of the factors leading to excessive price escapes are the herd behavior and the excessive trust in knowledge (Tufan, 2008: 80-81). For such reasons, securities are overvalued, and as purchases slow down, the effect of the balloon decreases backwards. When positive information comes to the market, investors are overly optimistic, and when bad news comes, they can behave in an overly pessimistic way.

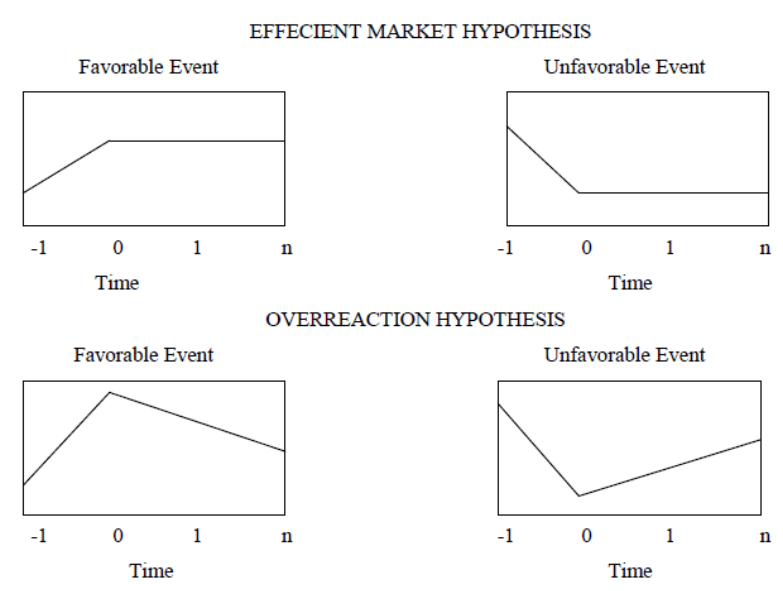

Figure 1. Stocks based on Effective Market Hypothesis and Overreaction Hypothesis

Source: Brown, Harlow and Tinic (1988) and Shachmurove (2002) 


\section{Relevant Literature}

There are a number of studies investigating the validity of the overreaction hypothesis in Stock Exchange Istanbul. (2008b) for the period 1989-2000, Durukan (2004) for the period 1988-2003, Yücel and Taşkın (2007) for the period 1992-2005 for the study of the hypothesis of overreaction exists in the Borsa Istanbul . Doğukanlı and Ergün (2011) also showed the existence of the hypothesis of overreaction in their work. The authors used the monthly returns of the stocks that were continuously included in the BIST indices in 1998-2008 period. Doğukanlı et al. (2012) tested the validity of the overreaction hypothesis in the Borsa Istanbul and whether the opposite investment strategies are beneficial in obtaining returns on market returns for different time periods. According to the results of the analysis, most of the time, results have emerged that support the hypothesis of overreaction. Tunçel (2013) formed 4 periods with 146 shares for the period of 1998-2012. At the end of the study, the author shows the existence of an overreaction hypothesis in Borsa Istanbul. Akkoç and Özkan (2013) also examined investors' reactions to important political and economic news in Borsa Istanbul. The authors used stock indices in the period of 2004-2011 and did not reach the evidence supporting the hypershot hypothesis. Thus, compared to the previous academic studies, Borsa Istanbul became more effective.

There are a number of academic studies that show evidence of overreaction when the stock exchange is traded outside Istanbul. Some of these evidences include De Bondt and Thaler (1985), Brown and Harlow (1988), Dissanaike (1997), Shachmurove (2002), Bauman, Conover and Miller (1999), Brown, Harlow and Tinic ). De Bondt and Thaler (1985) show that most people are overly sensitive and overactive to unexpected and striking news. The authors found that previously lost portfolios performed better than previously earning portfolios. According to the authors' study, they found that previously lost stocks in the 36 month time period provided 25\% higher returns than the winners. Brown and Harlow (1988) also found evidence that stocks in the New York Stock Exchange, which had previously been lost to investors, had excessive reaction. The Dissanaike (1997) FT500 index worked monthly for the period 1.1.1975-1.1.1991, and the experimental results obtained were consistent with the overreaction hypothesis. Bremer and Sweeney (1991) suggest that subsequent 10-day excess return losses are higher than expected returns, suggesting that the price correction lasts for 2 days.

Shachmurove (2002) suggests that small markets are more open to non-rational behavior. In his study, he investigated whether investors were overreacting in the stock exchanges of the small and medium-sized 13 countries, including Turkey. In the study of 1996 and earlier data, it was concluded that the overreaction hypothesis is valid in Turkey, Luxembourg, Norway and the Netherlands. Bauman, Conover and Miller (1999) studied the book to market ratio and earnings per share(EPS) ratios of stock markets in 21 countries. In the authors' work; Found that high yields are linked to low growth in the past, showing that they are overreacting in stock markets. The authors have found that stock prices are performing better than others in growth rates for some reasons. These are: Investors are overreacting to historical growth rates per share. The second reason, investors and analysts, assumes that the growth of earnings per share figures will continue in the future. In addition, the influence of 
the small firm also manifests itself. Companies with small book to market ratio provide superior performance than large firms.

In study of Brown, Harlow, and Tinic (1988), stock prices have shown a stronger response to bad financial news than good news. The authors have worked with 200 large firms in the $\mathrm{S} \&$ P 500 in the period 1962-1985.

All of these studies are investigating whether the price movements in the stock market indices are over-weighted against current economic developments. There is, however, a small number of studies that measure whether an inhibitory reaction is excessive depending on another index. De Medeiros (2005) investigated the effect of the movements in the Dow Jones index on the Bovespa index for the period of $1994-2005$. The author found evidence that the Bovespa stock market was overreacting against the positive shocks resulting from the Dow Jones index, while the negative shocks were showing a low response. This also shows that Bovespa does not provide effective market conditions. In this study, parallel to the study of De Medeiros (2005), it is investigated whether the Dow Jones Industry index has caused overreaction on the Borsa Istanbul 100 index.

\section{Method and Findings}

The aim of the study is to find out whether the Borsa Istanbul 100 Index (BIST-100) is overreacting in response to positive or negative shocks in the Dow Jones Industry Avarage Index (DJIA). For this reason, the daily closing prices of both indices between January 4, 2010 and June 1, 2016 are used in the study. Daily data appear to be used extensively for similar purposes.

The design of the worker is similar to the work of Brown, Harlow and Tinic (1988), Shachmurove (2002) and De Medeiros (2005). In the study, the DJIA was used to calculate the positive and negative excess returns of the BIST-100 index. Thus, the cumulative abnormal return and volatility of BIST-100 after an event becomes measurable. The daily closing prices of these indices were used in the study, taking into account the periods 01

January 2010 - 01 June 2016 for the BIST-100 index $\left(I_{t}^{B I S T-100}\right)$ and DJIA $\left(I_{t}^{D J I A}\right)$ data. In

order to calculate the cumulative abnormal result of BIST-100 after an event, the following methodology was applied;

- The daily returns of the BIST- 100 index and the DJIA are calculated;

$$
R_{t}^{B I S T-100}=\log \frac{I_{t}^{B I S T-100}}{I_{t-1}^{B D S T-100}} \text { and } R_{t}^{D J I A}=\log \frac{I_{t}^{D J I A}}{I_{t-1}^{D J I A}}
$$

- Then, A simple regression equation was established between the BIST-100 return and the DJIA obtained as follows.

$$
R_{t}^{B I S T-100}=\alpha+\beta R_{t}^{D J I A}+u_{t}
$$


- Some definitions were made on the residuals $\left(\hat{u}_{t}=R_{t}-\hat{R}_{t}\right)$ obtained from the regression;

$$
\begin{gathered}
\text { positive event occurs on time } t \text { if } \hat{u}_{t} \geq 0.025 \\
\text { negative event occurs on time } t \text { if } \hat{u}_{t} \leq-0.025 \\
\text { represents uneventful time if }-0.025 \leq \hat{u}_{t} \leq 0.025
\end{gathered}
$$

- The abnormal return on time $\mathrm{t}$ following the unexpected event of BIST 100 index is calculated as follows;

$$
A R_{t d}=R_{t d}-\bar{R}_{m}
$$

Where $R_{t d}$ is the index of the time following the $\mathrm{d}$ event, and $\bar{R}_{m}$ is the average index of the index on the uneventful time

- Finally, the cumulative abnormal return of BIST-100 index is calculated as follows;

$$
C A R_{t}=C A R_{t-1}+\overline{A R}_{t}
$$

where $\overline{A R}_{t}$ is the average of the abnormal return of BIST-100.

According to Mckinlay (1997) study, $C A R_{t}$ is determined by statistical significance $t$ test

$$
\left(t=\frac{C A R_{p t}}{\left[\operatorname{var}\left(\operatorname{CAR}_{p t}\right)\right]^{1 / 2}}\right)
$$

The charts of BIST-100 index and DJIA used in the analysis are as in Figure 2; BIST-100
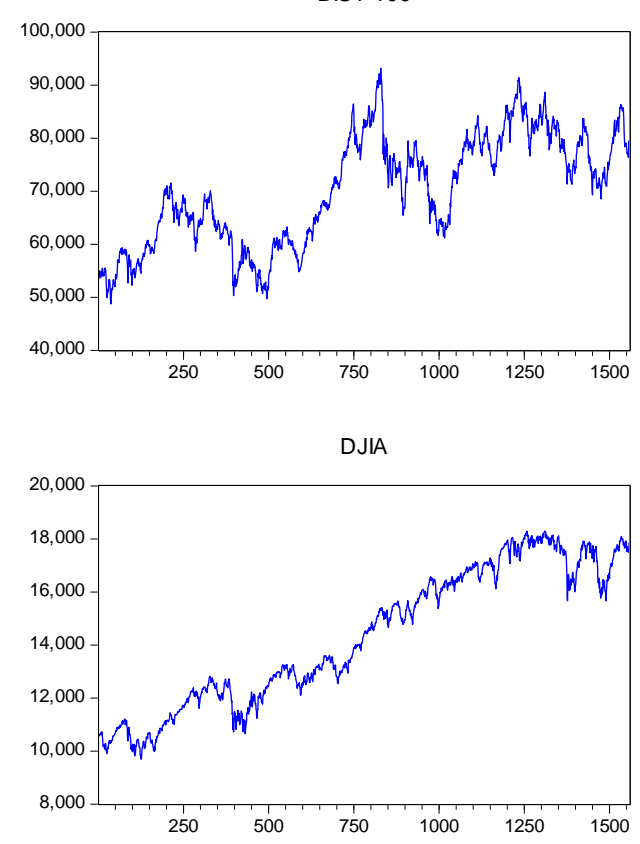

Figure 2. DJIA and BIST-100 Index Chart 
To determine the positive and negative events on the BIST-100 index, we checked whether the series were stationary before the regression equation was established between the BIST-100 and the DJIA index. Table 1 shows the results.

Table 1. ADF Unit Root Test Results

\begin{tabular}{|l|l|l|l|l|l|}
\hline \multirow{2}{*}{ All Period } & \multirow{2}{*}{ Test Form } & \multirow{2}{*}{ ADF Value } & \multicolumn{3}{l|}{ Davidson ve Mackinnon Critical Values } \\
\cline { 4 - 6 } & & $\% 1$ & $\% 5$ & $\% 10$ \\
\hline BIST-100 & Level + Constant Term & -3.04 & -3.96 & -3.41 & -3.12 \\
\hline Log_BIST-100 & Level + Constant Term & -3.01 & -3.96 & -3.41 & -3.12 \\
\hline BIST-100_d1 & Level + Constant Term & $-40.03 * * *$ & -3.96 & -3.41 & -3.12 \\
\hline DJIA & Level + Constant Term & $-3.48 * *$ & -3.96 & -3.41 & -3.12 \\
\hline Log_DJIA & Level + Constant Term & $-3.43 * *$ & -3.96 & -3.41 & -3.12 \\
\hline DJIA_d1 & Level + Constant Term & $-41.38 * * *$ & -3.96 & -3.41 & -3.12 \\
\hline
\end{tabular}

According to the ADF test results, the first differences of the variables were found to be stationary when the BIST-100 and DJIA variables and their logarithms were not stable at the $1 \%$ significance level. According to the results of the ADF test, it is concluded that both series are not stationary and that the first differences of the series are stationary and that the obtained residuals are stable. Therefore, the estimation of regression with the variables BIST-100 and DJIA reveals the problem of spurious regression. To solve this problem, the Engle-Granger estimation technique was used to estimate the regression by taking the logarithms of the series, and the BIST-100 $\operatorname{return}\left(R_{t}^{B I S T-100}\right.$ or DLOGBIST-100) was regressed on the DJIA $\left(R_{t}^{\text {DJIA }}\right.$ or DLOGDJIA) by using the residuals(error correction term $=$ $\mathrm{U}(-1)$ ) obtained from this cointegrated regression. The following table gives the estimation results of this regression.

Table 2. Regression Estimation Results

\begin{tabular}{|l|l|l|l|l|}
\hline \multicolumn{2}{|l|}{ Dependent Variable: DLOGBIST-100 } & & \\
\hline \multicolumn{2}{|l|}{ Method: Least Squares } & & \\
\hline \multicolumn{2}{|l|}{ Sample (adjusted): 21560} & & \\
\hline \multicolumn{2}{|l|}{ Included observations: 1559 after adjustments } & \\
\hline Variable & Coefficient & Std. Error & t-Statistic & Prob. \\
\hline C & $5.68 E-05$ & 0.000355 & 0.159977 & 0.8729 \\
\hline DLOGDJIA & 0.557094 & 0.037936 & 14.68493 & 0.0000 \\
\hline U(-1) & -0.013024 & 0.004085 & -3.188444 & 0.0015 \\
\hline R-squared & 0.125768 & Durbin-Watson stat & 2.111677 \\
\hline $\begin{array}{l}\text { S.E. of regression } \\
\text { 0.013998 }\end{array}$ & 0.013998 & F-statistic & & \\
\hline
\end{tabular}




\section{Macrothink}

Business and Economic Research

ISSN 2162-4860

2016, Vol. 6, No. 2

The residuals obtained from the regression were determined to represent the days when positive events occurred when $\hat{u}_{t} \geq 0.025$, negative days when $\hat{u}_{t} \leq-0.025$ and negative

days when $-0.025 \leq \hat{u}_{t} \leq 0.025$. Thus, between January 1, 2010 and June 1, 2016, there were 44 positive events and 54 negative events. The response to the positive and negative events of the mean cumulative abnormal return of the BIST-100 index obtained in the study is shown in Figure-2. The cumulative abnormal return to be used for testing hypotheses in this framework is more clear than volatility statistics because it is based on key market activity tests (De Medeiros, 2005).
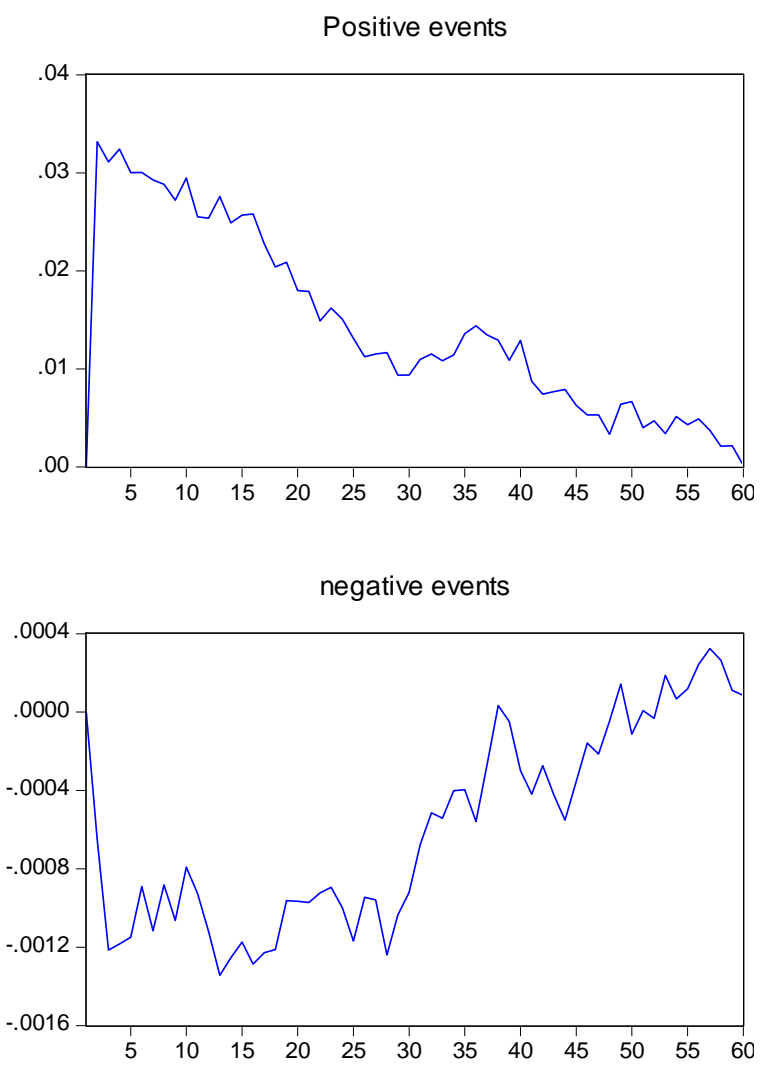

Figure 3. Cumulative Abnormal Returns After Positive and Negative Events

The average cumulative abnormal return of the BIST-100 index jumps about +0.0331 units, or about $3.3 \%$ (meaning $1 \%$ significance) when there is a positive event in the DJIA when looking at the average cumulative abnormal return behavior of the BIS-100 index. It can be said that at the 0th day there is an overreaction because the prices continue to fall when the average cumulative abnormal return of BIST-100 index up to 60 days is observed. As a result of the findings in this case, it can be said that BIST-100 supports the overreaction hypothesis of the index in case of a positive event. Lasfer, Melnik, and Thomas (2003) reported a cumulative abnormal return of about $0.6 \%$ and $1.5 \%$ within 5 days, respectively, in the same study conducted for developed and developing countries. In a similar study by De Medeiros 
(2005) for the Brazilian stock exchange (Bovespa), it is seen that the approximate cumulative abnormal return is similar to this study by about $3 \%$.

The BIST-100 index is different from the situation in which a positive event occurs, while the average cumulative abnormal return is less likely to occur when a negative event occurs. When there is a negative event, the average cumulative abnormal return decrease in the BIST-100 index is about $0.06 \%$ (meaning at $10 \%$ level). At the end of the 2nd day, this ratio is up to $0.12 \%$. When we examine cumulative abnormal returns until the 30th day, stock prices fluctuate indefinitely. Thus, when the reaction of stock prices is examined until the 30th day; It can be said that this behavior is an application of the effective market hypothesis $(\mathrm{EMH})$, since BIST-100 index occurrence is seen to stabilize around a new threshold value in the event of a negative event. When the average cumulative abnormal return increase of BIST-100 index up to 60 days is examined, it can be said that the prices are still falling and there is an excessive reaction on day 0 . As a result of the findings obtained in this case, it can be said that the BIST-100 index support the overreaction hypothesis when there is a negative event. In this case, the BIST-100 is overreacting when DJIA is experiencing both positive and negative developments. The surviving situation indicates that the effecient market hypothesis is not valid. In studies of Lasfer, Melnik and Thomas (2003) for developed and developing countries, it is observed that in the case of a negative event, the cumulative abnormal return line decreased by about $0.14 \%$ and $0.5 \%$. In a similar study by De Medeiros (2005) for the Brazilian stock exchange, this is about $3.4 \%$ when there is a negative event.

\section{Conclusion}

The study is to investigate whether the Borsa Istanbul 100 Index (BIST-100) is overreacting to the positive and negative events that occurred in the Dow Jones industry index. The daily closing price data for the trading days between January 4, 2010 and June 1, 2016 of the two indices are used in the study.

In the face of the positive developments in DJIA, the BIST-100 index had a normal return first, but at the end of the 60th day, this return was lifted. The results are statistically significant. For this reason, it can be said that the hypothesis of overreaction applies. In negative developments in DJIA, negative abnormal returns were found in BIST-100 index. All losses were compensated by reversed price movements that started after 30 days. However, these return corrections in the 30-60 days are not statistically significant. For this reason, it can not be said that it is compatible with the overreaction hypothesis. When there is a positive development in DJIA, the impact on the BIST-100 index resembles the response of Bovespa index to DJIA. The Bovespa index is declining when there is a negative development in DJIA. These falling returns are not corrected for 60 days, and even the drop in yields continues. Thus, it can be said that the reactions of BIST-100 index to DJIA are similar to the reactions of Bovespa to DJIA. According to these results, it is suggested that when DJIA is on the rise,

BIST investors should be careful against overreaction. Investors can get extra return by using this overreaction for speculation purposes. It is not statistically possible to say the same situation for periods when there are adverse events. 


\section{References}

Akkoc, S., \& ÖZKAN, N. (2013). An Empirical Investigation of the Uncertain Information Hypothesis: Evidence From Borsa Istanbul. Journal of BRSA Banking and Financial Markets, 7(2), 101-119.

Barak, O. (2008a). Davranışsal Finans Teori Uygulama, Gazi Kitabevi, Ankara.

Barak, O. (2008b). İMKB'de Aşırı Reaksiyon Anomali ve Davranışsal Finans Modellemesi Kapsamında Değerlendirilmesi, Gazi Üniversitesi İktisadi ve İdari Bilimler Fakültesi Dergisi, 10(1), 207-229.

Bremer, M., ve Sweeney, R. J. (1991). The Reversals of Large Stock Price Decreases. Journal of Finance, 46(2), 747-754. https://doi.org/10.1111/j.1540-6261.1991.tb02684.x

Brown, K. C., Harlow, W. V., \& Tinic, S. M. (1988). Risk aversion, uncertain information, and market efficiency. Journal of Financial Economics, 22(2), 355-385.

https://doi.org/10.1016/0304-405X(88)90075-X

Brown, K. C., \& W. V. Harlow. (1988). Market Overreaction: Magnitude and Intensity, Journal of Portfolio Management, 14(2), 6-13. https://doi.org/10.3905/jpm.1988.409137

DeBondt, W. F., \& Thaler, R. H. (1985). Does the Stock Market Overreact, Journal of Finance, 40, 793-805. https://doi.org/10.1111/j.1540-6261.1985.tb05004.x

De Medeiros, O. R. (2005). Reaction of the Brazilian stock market to positive and negative shocks. Available at SSRN 868464. https://doi.org/10.2139/ssrn.868464

Doğukanli, H., \& Ergün, A. G. B. (2011). Davranışsal Finans Etkin Piyasalara Karşı: Aşırı Tepki Hipotezinin imkb'de Araştırılması. Çukurova Üniversitesi Sosyal Bilimler Enstitüsü Dergisi, 20(1).

Dogukanli, H., Vural, G., \& Ergun, B. (2012). Using Various Portfolio Formation and Test Periods: An Examination of Overreaction in ISE. Istanbul Stock Exchange Review, 13(49), $1-18$.

Dissanaike, G. (1997). Do stock market investors overreact?. Journal of Business Finance \& Accounting, 24(1), 27-50. https://doi.org/10.1111/1468-5957.00093

Durukan, B. (2004). Aşırı Tepki Hipotezi: İstanbul Menkul Kıymetler Borsasından Kanıtlar. VIII. Ulusal Finans Sempozyumu, 137-142.

Fama, E. F. (1970). Efficient Capital Markets: A Review of Theory and Empirical Work. The Journal of Finance, 25(2), 383-417. https://doi.org/10.2307/2325486

Lasfer, M. A., Melnik, A., \& Thomas, D. C. (2003). Short-term reaction of stock markets in stressful circumstances. Journal of banking \& finance, 27(10), 1959-1977.

https://doi.org/10.1016/S0378-4266(02)00313-8

Shachmurove, Y. (2002). The Behavior of Secondary European Stock Markets to Positive and Negative Shocks, International Journal of Business, 7(2), 1-16. 
Tufan, E. (2008). Davranışsal Finans, İmaj Yayınları, Ankara.

Tunçel, A. K. (2013). Aşırı Tepki Hipotezinin Test Edilmesi: Borsa İstanbul Örneği. Uludăg Üniversitesi, İktisadi ve İdari Bilimler Fakültesi Dergisi, 1(32), 113-122.

Yücel, T., \& Taşkin, F. D. (2007). Aşırı tepki hipotezi ve İstanbul Menkul Kıymetler Borsası'ndan kan1tlar. Iktisat Isletme ve Finans, 22(260), 26-37.

https://doi.org/10.3848/iif.2007.260.0132

\section{Appendix: 1}

Table 3. Market Response to Positive and Negative Shocks

\begin{tabular}{|c|c|c|c|c|c|}
\hline & $\begin{array}{c}\text { The Market's Response } \\
\text { to Positive Events }\end{array}$ & $\begin{array}{c}\text { The Market's } \\
\text { Response to Negative } \\
\text { Events }\end{array}$ & & $\begin{array}{c}\text { The Market's } \\
\text { Response to Positive } \\
\text { Events }\end{array}$ & $\begin{array}{l}\text { The Market's } \\
\text { Response to } \\
\text { Negative Events }\end{array}$ \\
\hline Day & CAR & CAR & Day & CAR & CAR \\
\hline 1 & $0.033153433 *$ & $-0.000652572 * * *$ & 31 & 0.011503109 & -0.000513907 \\
\hline 2 & $0.031102372 *$ & $-0.001215031^{*}$ & 32 & 0.010819225 & -0.000541984 \\
\hline 3 & $0.032407001 *$ & $-0.001184074 * *$ & 33 & 0.01141432 & -0.000401083 \\
\hline 4 & $0.030017047 *$ & $-0.001149346^{* *}$ & 34 & 0.013588746 & -0.000395968 \\
\hline 5 & $0.030037326^{*}$ & -0.000890404 & 35 & 0.014396321 & -0.000558589 \\
\hline 6 & $0.029276278^{*}$ & $-0.001115309 * *$ & 36 & 0.013454239 & -0.000271799 \\
\hline 7 & $0.02883245^{*}$ & $-0.000882276^{* *}$ & 37 & 0.012919501 & $3.3255 \mathrm{E}-05$ \\
\hline 8 & $0.027203573 *$ & $-0.001063314 * *$ & 38 & 0.010872623 & $-4.8446 \mathrm{E}-05$ \\
\hline 9 & $0.02946804 *$ & $-0.000792299 * * *$ & 39 & 0.012891978 & -0.000298532 \\
\hline 10 & $0.025499923 *$ & $-0.000925888 * *$ & 40 & 0.008737925 & -0.000418723 \\
\hline 11 & $0.025372226^{*}$ & $-0.00111969 * *$ & 41 & 0.007418814 & -0.000273349 \\
\hline 12 & $0.027583572 *$ & $-0.001343181 * *$ & 42 & 0.007666986 & -0.000425459 \\
\hline 13 & $0.024885928 *$ & $-0.001254253 * *$ & 43 & 0.007887219 & -0.000551396 \\
\hline 14 & $0.025670185^{*}$ & $-0.001174587 * *$ & 44 & 0.006274414 & -0.000353083 \\
\hline 15 & $0.025788159 *$ & $-0.001286099 *$ & 45 & 0.005306698 & -0.000158277 \\
\hline 16 & $0.022729796^{* *}$ & $-0.001227578^{*}$ & 46 & 0.00530404 & -0.000214256 \\
\hline 17 & $0.020388611 * *$ & $-0.001211991 * *$ & 47 & 0.003311293 & $-4.65158 \mathrm{E}-05$ \\
\hline 18 & $0.020867808 * *$ & $-0.000962684 * *$ & 48 & 0.006394468 & 0.000142748 \\
\hline 19 & $0.017980297 * *$ & $-0.000965308 * *$ & 49 & 0.00665819 & -0.000112897 \\
\hline 20 & $0.017898222 * *$ & $-0.000971952 * *$ & 50 & 0.003991479 & 7.42396E-06 \\
\hline 21 & $0.014895846^{* * * *}$ & $-0.000922472 * *$ & 51 & 0.0047038 & $-3.18088 \mathrm{E}-05$ \\
\hline 22 & $0.016192715^{* *}$ & $-0.000894466^{* *}$ & 52 & 0.003390572 & 0.00018737 \\
\hline 23 & $0.015047717 * * *$ & $-0.000999508 * *$ & 53 & 0.005129797 & $6.70849 \mathrm{E}-05$ \\
\hline 24 & $0.013103747 * * *$ & $-0.001167736^{* *}$ & 54 & 0.004288069 & 0.000118816 \\
\hline 25 & 0.01123063 & $-0.000944858 * *$ & 55 & 0.004903463 & 0.000243345 \\
\hline 26 & 0.011508395 & $-0.00095904 * *$ & 56 & 0.003732476 & 0.000323953 \\
\hline 27 & 0.011647923 & $-0.001240065^{* *}$ & 57 & 0.002105276 & 0.000264879 \\
\hline 28 & 0.009341823 & $-0.001034359 * *$ & 58 & 0.002144873 & 0.000111468 \\
\hline 29 & 0.009365523 & $-0.000919688 * *$ & 59 & 0.000152157 & $8.45983 \mathrm{E}-05$ \\
\hline 30 & 0.010957615 & -0.000676236 & 60 & $2.08167 \mathrm{E}-17$ & $2.43945 \mathrm{E}-19$ \\
\hline
\end{tabular}

$* \% 1, * * \% 5$ and $* * * \% 10$ represent significance levels. 


\section{Copyright Disclaimer}

Copyright for this article is retained by the author(s), with first publication rights granted to the journal.

This is an open-access article distributed under the terms and conditions of the Creative Commons Attribution license (http://creativecommons.org/licenses/by/3.0/). 